\title{
LITERARY RESPONSES TO ANIMAL EXPERIMENTATION IN SEVENTEENTH- AND EIGHTEENTH-CENTURY BRITAIN
}

\author{
by
}

\section{ANDREAS-HOLGER MAEHLE *}

The fact that British men of letters in the seventeenth and eighteenth centuries commented on the subject of animal experimentation is well known. Apart from anti-vivisectionists and modern advocates of animal rights, who have been keen to cite the most critical of these responses, ${ }^{1}$ scholars have considered them in three main areas of research. In the history of ideas some of those literary sources have been used to elucidate the origins of animal protection and the development of man's relationship to the animal world. ${ }^{2}$ In the history of literature itself they have sometimes been helpful in analysing the interaction between the so-called "New Science", i.e. the science following Francis Bacon's programme of observation and experiment, and contemporary literature. ${ }^{3}$ And recently, in the history of medicine,

*Dr Andreas-Holger Maehle, Institut für Geschichte der Medizin der Georg-August-Universität Göttingen, Humboldtallee 11, 3400 Göttingen, Federal Republic of Germany.

I owe special thanks to Professor Ulrich Tröhler, Göttingen, and to Dr N. A. Rupke, Oxford, for substantial advice on preparing this paper.

\footnotetext{
' See 'Samuel Johnson', Zoophilist, 1884, 3: 288; O. A. Ellissen, 'Samuel Johnson über Vivisektion', Tierund Menschenfreund, 1916, 36: 85-6; John Vyvyan, In pity and in anger, London, Michael Joseph, 1969, pp. 24-6, 34, 142; Peter Singer, Animal liberation, New York, New York Review, 1975, p. 221; Richard D. Ryder, 'The struggle against speciesism', in David Paterson and R. D. Ryder (eds.), Animals' rights-a symposium, Fontwell and London, Centaur Press, 1979, pp. 3-14, on pp. 3, 8; idem, Victims of science, London and Fontwell, National Anti-Vivisection Society and Centaur Press, 1983, pp. 127-9; Stephen R. L. Clark, The moral status of animals, Oxford University Press, 1984, p. 33.

${ }^{2}$ See William Edward Hartpole Lecky, A history of England in the eighteenth century, 8 vols., London, Longmans Green, 1878-90, vol. 1, pp. 551-2; Dix Harwood, Love for animals and how it developed in Great Britain, New York, Columbia University, 1928, pp. 112-13, 257, 297-8, 306. (A popularly-written book on Harwood's topic is E. S. Turner, All Heaven in a rage, London, Michael Joseph, 1964, which quotes literary responses to animal experiments on pp. 48, 66, 68, 77-8); Dagobert de Levie, The modern idea of the prevention of cruelty to animals and its reflection in English poetry, New York, S. F. Vanni, 1947, p. 15; Keith Thomas, Man and the natural world - a history of the modern sensibility, New York, Pantheon Books, 1983, pp. 178, 188.

${ }^{3}$ See Carson S. Duncan, The New Science and English literature in the Classical period, Menasha, Wis., Collegiate Press, 1913; John James Brown, 'Samuel Johnson and eighteenth-century science', Ph. D. thesis, Yale University, New Haven, Conn., 1943, pp. 216-20; Marjorie Nicolson, Science and imagination, Ithaca, New York, Great Seal Books, 1956, pp. 110-234; idem, Pepys' Diary and the New' Science, Charlottesville, University Press of Virginia, 1965, pp. 55-175; Herbert Silvette, The doctor on the stage. Medicine and medical men in seventeenth-century England, ed. Francelia Butler, Knoxville, University of Tennessee Press, 1967, pp. 153-81, 235-71; Marjorie Nicolson and G. S. Rousseau, "This long disease, my life"-Alexander Pope and the sciences, Princeton, NJ, Princeton University Press, 1968, pp. 87-109.
} 


\section{Andreas-Holger Maehle}

literary comments on animal experiments have begun to be consulted for what they tell us about lay attitudes towards this practice. ${ }^{4}$ Yet thus far, no synopsis has been written of literary responses to animal experiments as a phenomenon as such, in its chronological development, nor of the function of the respective literary genres. The present study aims to fill this gap, with due regard to all three fields of interest.

\section{WITS AND VIRTUOSI: SATIRE ON ANIMAL EXPERIMENTS}

When the Royal Society of London for the Improving of Natural Knowledge was given its charter by Charles II in 1662, it was well on its way to become a most important institutional framework for Baconian experimental science, including physiological and toxicological experiments on animals. ${ }^{5}$ Contemporary men of letters were well aware of the experiments performed at Gresham College. The New Science of the "virtuosi", 6 as the Fellows of the Royal Society were commonly called, provoked different reactions among the literati. A few of them adopted the scientists' scepticism towards classical Aristotelian principles or made the new scientific findings a source of poetical inspiration and imagery. ${ }^{7}$ John Dryden, himself a member of the Society, even tried to introduce the inductive method in the field of literary criticism, hoping to create a form of progress in poetry similar to that in the natural sciences. ${ }^{8}$ Many others, however, the so-called "Wits and Railleurs" of the Restoration literary scene, made the virtuosi's observational and experimental endeavours a fashionable target for vehement satirical attacks. ${ }^{9}$ Although the young Royal Society faced other serious charges, such as that of propagating atheism and of undermining the traditional educational system of the universities, ${ }^{10}$ it was mainly the mockery of men of letters that led to its famous defence by the scientists' historian Thomas Sprat in

\footnotetext{
${ }^{4}$ See Lloyd G. Stevenson, 'Religious elements in the background of the British anti-vivisection movement', Yale J. Biol. Med., 1956, 29: 125-57, on p. 147; A. E. Clark-Kennedy, Stephen Hales, D.D., F.R.S.- an eighteenth century biography, Farnborough, Hants., Gregg Press, 1965, pp. 55-7; Richard D. French, Antivivisection and medical science in Victorian society, Princeton and London, Princeton University Press, 1975, pp. 15-17; D. G. C. Allan and R. E. Schofield, Stephen Hales: scientist and philanthropist, London, Scolar Press, 1980, p. 29; Andreas-Holger Maehle and Ulrich Tröhler, 'Animal experimentation from antiquity to the end of the eighteenth century: attitudes and arguments', in Nicolaas A. Rupke (ed.), Vivisection in historical perspective, London, New York, and Sydney, Croom Helm, 1987, pp. 14-47, on pp. 29-33.

"In this paper the term "animal experimentation" is used in a broad sense including all kinds of experimental observation on every kind of living animals. The term "vivisection", however, is used in its narrow and original seventeenth- and eighteenth-century meaning, i.e. the (partial) dissection of, or surgical intervention on, living beings for the purpose of research; cf. Maehle and Tröhler, op. cit., note 4 above, p. 14.

${ }^{6}$ See Walter E. Houghton Jr., 'The English virtuoso in the seventeenth century', J. Hist. Ideas, 1942, 3: 51-73, 190-219.

${ }^{7}$ See Duncan, op. cit., note 3 above, pp. 133-46; Richard Foster Jones, 'Science and criticism in the neo-classical age of English literature', in idem (ed.), The seventeenth century-studies in the history of English thought and literature from Bacon to Pope, Stanford University Press, 1951, pp. 41-74.

${ }^{8}$ Cf. ibid., pp. 44-9.

${ }^{9}$ See Duncan, op. cit., note 3 above, pp. 67-132; Nicolson, Science and imagination, op. cit. note 3 above, pp. 110-234; idem, Pepys' Diary, op. cit., note 3 above, pp. 103-75.

${ }^{10}$ See Richard Foster Jones, 'The background of the attack on science in the Age of Pope', in James L. Clifford and Louis A. Landa (eds.), Pope and his contemporaries-essays presented to George Sherburn, New York, Oxford University Press, 1949, pp. 96-113.
} 


\section{Literary responses to animal experimentation}

1667. ${ }^{11}$ The satirists had many butts, equally deriding the Society's astronomical, physical, and chemical studies and those in the fields of microscopy, anatomy, physiology, and toxicology. Here the satires against animal experimentation will be examined.

The 'Ballad of Gresham Colledge', an anonymous manuscript probably written around 1662, seems to have had a wide circulation among educated people during the Society's early years. ${ }^{12}$ It ridiculed Robert Boyle's experiments on the physical properties of air and on the physiology of respiration. Especially his air-pump experiments, in which he had studied the behaviour of various animals in an air-free glass vessel, ${ }^{13}$ attracted the attention of the satirist. In 1661, the virtuoso John Evelyn had entertained the Danish ambassador at Gresham College with some Boylean experiments with the air-pump. ${ }^{14}$ This occasion was aptly mocked by the author of the 'Ballad':

To the Danish Agent late was showne

That where noe Ayre is, there's noe breath.

A glasse this secret did make knowne

Where[in] a Catt was put to death.

Out of the glasse the Ayre being screwed,

Pusse dyed and ne're so much as mewed. ${ }^{15}$

The first outstanding writer of such virtuoso-satire, as we may call it, was Samuel Butler. In 1664, in his burlesque poem 'Hudibras', he ridiculed the microscopical observations of Robert Hooke, which the latter had just demonstrated before the Royal Society and was about to publish in his Micrographia $(1665) .{ }^{16}$ Sidrophel, the poet's quack astrologer, studies the heart-beat in "a Dappled Louse's back", the jump of a flea, and "Maggots breed in Rotten Cheese" ${ }^{17}$ Butler went on to write a satire in prose on the Society's toxicological animal experiments. Here he derided Boyle by imitating his circumstantial style and moralizing tone and poked fun at Walter

${ }^{11} \mathrm{Cf}$. Thomas Sprat, The history of the Royal-Society of London, For the Improving of Natural Knowledge, London, J. Martyn, 1667, p. 417; see also Albert Rosenberg, 'Bishop Sprat on science and imagery', Isis, 1952, 43: 220-2; F. V. Morley, 'The Royal Society as an "infant Hercules"', New' Scientist, 1959, 6: $1239-41$.

${ }^{12}$ Cf. Dorothy Stimson, “"Ballad of Gresham Colledge”, Isis, 1932, 18: 103-17; F. Sherwood Taylor, 'An early satirical poem on the Royal Society', Notes Rec. R. Soc. Lond., 1946, 4: 37-46; Nicolson, Pepys' Diary, op. cit., note 3 above, pp. 115-17.

13 See Robert Boyle, New experiments physico-mechanical, touching the spring of the air, and its effects, Oxford, H. Hall, Tho. Robinson, 1662, pp. 169-99; see also Robert G. Frank Jr., Harvey and the Oxford physiologists - a study of scientific ideas, Berkeley, Los Angeles, and London, University of California Press, 1980, pp. 142-54.

${ }^{14}$ Cf. E. S. de Beer (ed.), The diary of John Evelyn, 6 vols., Oxford, Clarendon Press, 1955, vol. 3, p. 271; Thomas Birch, The history of the Royal Society of London for Improving of Natural Knowledge, 4 vols., London, A. Millar, 1756-7, (repr. Hildesheim, Olms, 1968), vol. 1, p. 16.

${ }_{15}$ Quoted from Stimson, op. cit., note 12 above, p. 110.

16 Samuel Butler, Hudibras, ed. John Wilders, Oxford, Clarendon Press, 1967; Robert Hooke, Micrographia, 1665, repr. in R. T. Gunther (ed.), Early science in Oxford, vol. 13, The life and work of Robert Hooke (part $V$ ), Oxford, Printed for the Subscribers, 1938.

${ }^{17}$ Butler, op. cit., note 16 above, p. 161; cf. Hooke, op. cit., note 16 above, pp. 210-15. 
Charleton, physician-in-ordinary to Charles II and member of the Royal Society, in the act of examining a poisoned dog: ${ }^{18}$

Do you observe ... that domestic Animal, the Vassal and menial Servant of Man, on whom he waits like a Lacquey by Day, and watches like a Constable by Night, how quiet and unconcerned it stands whilst the industrious and accurate Dr. Charlton with his judicious Finger examines the arterial Pulsation of its left Foreleg; a civil Office, wherein both Doctor and Dog, Physician and Patient with equal Industry contest, who shall contribute most to the experimental Improvement of this learned and illustrious Society... 19

Through his satirical descriptions of the virtuosi-also to be found in his 'Elephant in the Moon', 'Virtuoso', and 'Heroical Epistle of Hudibras to Sidrophel'20_Butler was expressing a serious criticism of the new experimental scientists. He believed that they debased their talents in useless trivialities instead of applying themselves to acquire practical and useful knowledge. ${ }^{21}$ It was in this sense that he also satirized the Society's animal experiments as a waste of time. Butler was evidently not concerned, however, about the possible suffering of experimental animals. 22

This strictly anthropocentric view of animal experimentation became yet more pronounced in the literary work of another Restoration wit who had been one of the pallbearers at Butler's funeral in 1680: Thomas Shadwell (c.1641-92). ${ }^{23}$ Four years earlier, in May 1676, his comedy The Virtuoso had been played for the first time at the Duke's Theatre in Dorset Garden. ${ }^{24}$ In the person of his leading character, the "Virtuoso" Sir Nicholas Gimcrack, Shadwell amply satirized the Royal Society scientists and their multifarious microscopical, telescopical, physico-chemical, anatomical, and physiological studies, including animal experiments. ${ }^{25}$ Sir Nicholas prides himself on having found "that an animal may be preserv'd without respiration when the windpipe's cut in two, by follicular impulsion of air: to wit, by blowing wind with a pair of bellows into the lungs".- "I have heard of a creature preserv'd by blowing wind in the breech, sir", is the irreverent answer of Longvil, a young

18 Butler, 'An occasional reflection on Dr. Charlton's feeling a dog's pulse at Gresham-College. By R. B. Esq. to Lyndamore', in R. Thyer (ed.), The genuine remains in verse and prose of Mr. Samuel Butler, 2 vols., London, J. and R. Tonson, 1759, vol. 1, pp. 404-10; cf. Robert Boyle, Occasional reflections upon several subjects, London, W. Wilson, H. Herringman, 1665, pp. 161-3, 245-6, 256-7. For another satire on Boyle's Occasional reflections see Jonathan Swift, 'A meditation upon a broom-stick' in William Alfred Eddy (ed.), Satires and personal writings by Jonathan Swift, London and New York, Oxford University Press, 1932, pp. 155-8.

19 Butler, op. cit., note 18 above, pp. 404-5. In fact, during the Society's meeting on 15 March 1665, a dog had been pricked with a needle that had been dipped into "Macassar powder": no effect was observed. Cf. Birch, op. cit., note 14 above, vol. 2, p. 23.

${ }^{20}$ See Butler, 'The elephant in the moon', in Thyer, op. cit., note 18 above, vol. 1, pp. 1--25; idem, 'A virtuoso', ibid., vol. 2, pp. 185-9; idem, op. cit. note 16 above, p. 188.

${ }^{21}$ Cf. ibid., Introduction, p. xxvi.

22 Effective anaesthesia became generally available for both animals and human beings only around 1850.

${ }^{23}$ Cf. Albert S. Borgman, Thomas Shadwell-his life and comedies, New York University Press, 1928, p. 36 .

${ }^{24}$ Thomas Shadwell, The virtuoso, ed. Marjorie Hope Nicolson and David Stuart Rhodes, London, Edward Arnold, 1966, Introduction, p. xii.

${ }^{25}$ See ibid., pp. xv-xxvi; Claude Lloyd, 'Shadwell and the Virtuosi', Publ. Mod. Lang. Assoc., 1929, 44: 472-94. 
"Gentleman of wit and sense". 26 In this dialogue Shadwell evidently mocked Hooke's "bellows-experiment", which the latter had performed together with Richard Lower at the Society's meeting on 10 October 1667. Hooke had cut away the ribs and diaphragm of a living dog, thus exposing the movements of its heart and lungs. During his observations, which lasted for more than an hour, he had kept the animal's respiration going by pumping a pair of bellows, the nose of which had been inserted into the dog's trachea. ${ }^{27}$

Like Butler, Shadwell did noc show any worry about animal suffering, focusing only on the seeming uselessness and absurdity of the experiment. ${ }^{28}$ Characteristically, however, his criticism of experimentation on human subjects was quite emphatic. After previous success with blood transfusion from animal to animal, in 1667 both the Royal Society and the French physician Jean Denis (c.1635-1704) had tried the first transfusions from animals to human beings. Two of Denis's patients died after the transfusions. ${ }^{29}$ Criticism of this is articulated by Old Snarl, the "Virtuoso's" uncle:

In sadness, nephew, I am asham'd of you. You will never leave lying and quacking with your transfusions and fool's tricks. I believe if the blood of an ass were transfus'd into a virtuoso, you would not know the emittent ass from the recipient philosopher ... In sadness, you deserve to be hang'd. You kill'd four or five that I know with your transfusion. $^{30}$

In another scene of his play Shadwell further implied that experimenting physicians were bad, even unscrupulous doctors. Thus Sir Nicholas in his consultation hour for poor patients merely distributes ready-written prescriptions in order to save time for his research and selects a "madman" for blood transfusion experiments. ${ }^{31}$ In this way Shadwell may have intimated that those who experiment on living animals did not hesitate to extend their experimentation to helpless human beings.

The Virtuoso was a successful Restoration comedy and was still performed at Lincoln's Inn Fields in $1705 .^{32}$ More than this, well into the eighteenth century the

${ }^{26}$ Shadwell, op. cit., note 24 above, pp. 47-8.

${ }^{27}$ Cf. Birch, op. cit., note 14 above, vol. 2, p. 198; Robert Hooke, 'An account of an experiment ... of preserving animals alive by blowing through their lungs with bellows', Phil. Trans. R. Soc., 1667, 2: 539-40; idem, 'An account of a dog dissected', in Sprat, op. cit., note 11 above, p. 232.

${ }^{28}$ See also his satire on transfusing blood from dog to dog, Shadwell, op. cit., note 24 above, p. 48 ; cf. Thomas Coxe, 'An account of another experiment of transfusion, viz. of bleeding a mangy into a sound dog', Phil. Trans. R. Soc., 1667, 2: 451-2.

29 On the British trials see Edmund King, 'An account of the experiment of transfusion, practised upon a man in London', ibid., pp. 557-9; Gunther, op. cit., note 16 above, vol. 9, Richard Lower, Tractatus de corde (1669), ed. K. J. Franklin, Oxford, Printed for the Subscribers, 1932, pp. 189-90; Birch, op. cit., note 14 above, vol. 2, pp. 214-16. On the French trials see 'An account of more tryals of transfusion ... chiefly in reference to its circumspect practise on man, Phil. Trans. R. Soc., 1667, 2: 517-25; 'A relation of some trials of the same operation [i.e. transfusion], lately made in France', ibid., 559-64; 'An extract. Of a letter, written by J. Denis . . touching a late cure of an inveterate phrensy by the transfusion of bloud', ibid., 1668, 2: 617-24; 'An extract of a printed letter . . . by M. Jean Denis . . . touching the differences risen about the transfusion of bloud', ibid., 1668, 3: 710-15; 'A letter . . . relating to the experiment of the transfusion of blood', ibid., 1669, 4: 1075-7. See also Harcourt Brown, 'Jean Denis and transfusion of blood, Paris, 1667-1668', Isis, 1948, 39: 15-29; A. D. Farr, 'The first human blood transfusion', Med. Hist., 1980, 24: 143-62.

${ }^{30}$ Shadwell, op. cit., note 24 above, pp. 51-2.

31 Cf. ibid., pp. 102-3, 107-8.

$32 \mathrm{Cf}$. ibid., Introduction, pp. xii-xiii. 


\section{Andreas-Holger Maehle}

scientific virtuoso served as a stock character of satire and comedy comparable to that of the incapable and avaricious physician. ${ }^{33}$ For example, the satirist Thomas Brown (1663-1704) used both characters to ridicule the Royal Society and the Royal College of Physicians. ${ }^{34}$ In 1710 the writer and politician Joseph Addison again presented Shadwell's Sir Nicholas Gimcrack in the widely read thrice-weekly paper the Tatler (1709-11), which he published together with his friend Richard Steele. ${ }^{35}$ Addison not only used the familiar satirical device to criticize the virtuosi, but in addition warned in all seriousness that those who spend all their time in studying the anatomy of minute and low animals would become alienated from the world of human affairs and "expose philosophy to the ridicule of the witty, and contempt of the ignorant". ${ }^{36}$ In his daily paper the Spectator (1711-12 and 1714) he continued to express this criticism. ${ }^{37}$ Jonathan Swift employed the by-then old virtuoso-satire when in 1726 he depicted the "grand Academy of Lagado" in Gulliver's travels. ${ }^{38}$ Among the many silly virtuosi Gulliver meets here is a physician who demonstrates his genuine method of curing the "Cholick" by "contrary Operations" on a dog: a large pair of bellows with a long slender muzzle is introduced into the dog's anus, and the animal is blown up until its intestines are near bursting point. After the dog has died from this procedure, the doctor tries to reanimate it by the very same "Operation". ${ }^{39}$ Swift's reference to both Hooke's original "bellows-experiment" and to Shadwell's satirical Virtuoso could hardly have escaped the informed readers' notice. ${ }^{\mathbf{4 0}}$ As late as 1737 the Gentleman's Magazine published a poem entitled 'The Virtuoso' written by Mark Akenside (1721-70). ${ }^{41}$ The interest seemed inexhaustible. $^{42}$ The recurrent essential message was: the observations and experiments of the virtuosi are useless to mankind, a mere waste of time and money. The study of "vermin" is unworthy of a true scholar. Moreover, it alienates the scientists from the-much more important-social and political world they live in.

\footnotetext{
${ }^{33}$ See Duncan, op. cit., note 3 above, pp. 67-132; Silvette, op. cit., note 3 above; Paul G. Brewster, 'Physician and surgeon as depicted in 16th and 17th century English literature', Osiris, 1962, 14: 13-32; Fielding H. Garrison, 'Medicine in the Tatler, Spectator and Guardian', Bull. Inst. Hist. Med., 1934, 2: 477-503.

${ }^{34}$ See Thomas Brown, 'Amusements serious and comical, calculated for the meridian of London', in The works of Mr. Thomas Brown, 4 vols., London, Sam Briscoe, 1720, vol. 3, pp. 1-100, on pp. 94-100.

35 Joseph Addison, 'The Tatler No. 216, August 26, 1710, No. 221, September 7, 1710', in The Tatler, 4 vols., ed. George A. Aitken, 1898-9, repr. Hildesheim and New York, Olms, 1970, vol. 4, pp. 110-13, 133-8.

${ }^{36}$ Ibid., vol. 4, pp. 110-11. See also 'The Tatler No. 119, January 12, 1709-10', ibid., vol. 3, pp. $27-31$.

37 Idem, 'The Spectator No. 21, March 24, 1711', in The Spectator, 5 vols., ed. Donald F. Bond, Oxford, Clarendon Press, 1965, vol. 1, pp. 88-92.

38 Jonathan Swift, Gulliver's Travels, ed. Herbert Davis, Oxford, Basil Blackwell, 1959, pp. $179-92$.

${ }^{39}$ Cf. ibid., p. 181.

40 See notes 26 and 27 above; see also Marjorie Nicolson and Nora M. Mohler, 'The scientific background of Swift's Voyage to Laputa', in Nicolson, Science and imagination, op. cit., note 3 above, pp. 110-54, on pp. 142-3.

${ }^{41}$ [Mark Akenside], 'The virtuoso; in imitation of Spencer's style and stanza', Gentleman's Mag., 1737, 7: 244-5; see also C. Lennart Carlson, The first magazine - a history of the Gentleman's Magazine, Westport, Conn., Greenwood Press, 1974, pp. 223-4.

${ }^{42}$ For further satires on virtuosi see Duncan, op. cit., note 3 above, pp. 67-132; Silvette, op. cit., note 3 above, pp. 153-81.
} 


\section{Literary responses to animal experimentation}

Experimentation on human beings provoked Shadwell's criticism, which, however, was tinged with the kind of mockery also directed at medical practitioners. Yet, as for animal suffering in experiments, there seems to have been no concern among the "Wits and Railleurs", at least initially. This is the more remarkable as some of the satirized seventeenth-century scientists themselves, such as Boyle, Hooke, and Lower, occasionally expressed a certain remorse about the infliction of pain on their animal subjects. ${ }^{43}$ Similarly Evelyn, a spectator at the performance of Hooke's "bellows-experiment", had noted in his diary: "This was an experiment of more cruelty than pleased me". ${ }^{44}$ However, in the early part of the eighteenth century, literary responses to animal experimentation began to change. While the old satirical style remained predominant, the element of cruelty in animal experimentation, and particularly in vivisection, ${ }^{45}$ started to attract the attention of writers. ${ }^{46}$ Akenside spoke of the virtuoso's "relentless hand, That oft with gory crimson was distain'd", articulating his aversion to vivisection. ${ }^{47}$ Similarly, in 1711 Addison revealed his feelings about vivisection, when he cited a particularly cruel experiment in the Spectator: a pregnant bitch is vivisected and one of its puppies pulled out of its womb; when the puppy is held to the bitch's mouth, the mother immediately starts licking it, seemingly oblivious to its own pain; when the puppy is removed, however, the bitch with its eyes fixed on the puppy, utters a wailing cry which seems to be caused by the loss of its young rather than by its own wounds. 48

Originally this experiment had been performed by Realdo Colombo (1516-59), but it was still discussed and possibly even repeated in the eighteenth century. ${ }^{49}$ On the one hand, Addison appreciated it as an impressive contribution to the study of animal instinct, because it demonstrated maternal "natural Love in Brutes". On the other hand, he called it "a very barbarous Experiment" and apologized to his readers for quoting "such an Instance of Cruelty". 50 This ambivalence may indicate that sensitivity to animal suffering was just beginning to enter the literary consciousness of the period, going beyond the traditional, satirical treatment of the subject. ${ }^{51}$

Another early example for this phenomenon can be found in the comedy The

\footnotetext{
${ }^{43}$ See Wallace Shugg, 'Humanitarian attitudes in the early animal experiments of the Royal Society', Ann. Sci., 1968, 24: 227-38; Maehle and Tröhler, op. cit., note 4 above, pp. 23-4; Malcolm R. Oster, 'The "Beame of Diuinity": animal suffering in the early thought of Robert Boyle', Br. J. Hist. Sci., 1989, 22: $151-79$.

${ }^{44}$ De Beer, op. cit., note 14 above, vol. 3, pp. 497-8.

${ }^{45}$ See notes 5 and 22 above.

46 It is revealing in this context that in the fourth of his Drapier's letters (1724) Swift employed "the last Howls of a Dog dissected alive" as a figure of speech to disparage the counter-attacks of his opponent William Wood; cf. Jonathan Swift, The drapier's letters and other works 1724-1725, ed. Herbert Davis, Oxford, Basil Blackwell, 1941, p. 54.

${ }^{47}$ Akenside, op. cit., note 41 above, p. 244.

${ }^{48}$ Cf. Addison, 'The Spectator No. 120, July 18, 1711', in op. cit., note 37 above, vol. 1, pp. 489-93, on p. 491.

${ }^{49}$ Cf. Realdo Colombo, De re anatomica libri $X V$, Venice, 1559, repr. Brussels, Culture et Civilisation, 1983, p. 258; Hester Hastings, Man and beast in French thought of the eighteenth century, Baltimore, Johns Hopkins Press, 1936, p. 271.

${ }^{30}$ Addison, op. cit., note 37 above, vol. 1, pp. 490-1.

${ }^{51}$ See also Stevenson, op. cit., note 4 above, p. 147.
} 


\section{Andreas-Holger Maehle}

Basset-Table (1705) by Susanna Centlivre (1669-1723)..$^{52}$ In the tradition of the Restoration dramatists, the poetess created the character of Valeria, "a philosophical Girl", who is a "virtuosa" or female counterpart to Shadwell's Sir Nicholas Gimcrack. ${ }^{53}$ Thus Valeria anatomizes insects and worms as well as dogs and studies the blood circulation in the tail of a fish fixed under the microscope. ${ }^{54}$ When she tells her cousin Lady Reveller, however, that she has dissected her pet dove in order to verify the "vulgar Notion" that doves lack gall, ${ }^{55}$ the following dialogue ensues:

LADY. Oh, barbarous! killed your pretty Dove.

VAL. Kill'd it! Why, what did you imagine I bred it up for? Can Animals, Insects, or Reptiles, be put to a nobler Use than to improve our Knowledge? Cousin, I'll give you this Jewel for your Italian Greyhound.

LADY. What to cut to pieces? Oh, horrid! he had need be a Soldier that ventures on you; for my Part, I should dream of nothing but Incision, Dissection, and Amputation, and always fancy the Knife at my Throat. ${ }^{56}$

Thus the cruelty of animal experimentation and dissection had become a prominent issue to the dramatist, even though Valeria's anatomical and physiological studies are themselves traditionally dismissed elsewhere in the play as "Whimsies" and "Ridiculous Learning". ${ }^{57}$ The killing of animals for scientific purposes had begun to be recognized as a moral problem, as Valeria's justification suggests. Suffering and deaths of animals had to be weighed against the improvement of human knowledge; and the nightmare of human vivisection, ${ }^{58}$ envisaged by Lady Reveller as the next step following animal vivisection, increased the doubts about the moral admissibility of animal experimentation.

In the course of the eighteenth century the aspect of cruelty became the central point of literary responses to animal experiments. Even so, cruelty could still be criticized in a humorous way, the satirical tradition of the Restoration period being strong and persistent. In 1740 the Gentleman's Magazine published the poem 'The Air-Pump'. "Junius", its pseudonymous author, ridiculed the Royal Society's Boylean air-pump experiments with animals by comparing them with the proverbial cruelties of the Roman Emperor Domitian. ${ }^{59}$ The possible step from animal to human experimentation was also satirized: Domitian, we read, would have tried the

\footnotetext{
52 Susanna Centlivre, 'The Basset-Table', in The dramatic works of the celebrated Mrs. Centlivre, 3 vols., London, 1872, repr. New York, AMS Press, 1968, vol. 1, pp. 199-258.

${ }^{53}$ Cf. John Wilson Bowyer, The celebrated Mrs. Centlivre, New York, Greenwood Press, 1968, pp. 71-4; Duncan, op. cit., note 3 above, pp. 87-90; Nicolson, Science and imagination, op. cit., note 3 above, pp. 187-8.

${ }_{54}$ Cf. Centlivre, op. cit., note 52 above, pp. 217, 227.

55 Cf. Thomas Browne, Pseudodoxia epidemica, ed. Robin Robbins, Oxford, Clarendon Press, 1981, pp. 168-71; Friedrich Sühling, Die Taube als religiöses Symbol im christlichen Altertum, Freiburg i. B., Herder, 1930, pp. 188-9.

56 Centlivre, op. cit., note 52 above, p. 218.

57 Cf. ibid., pp. 217, 228.

${ }^{58}$ For further satire on human vivisection see Centlivre's comedy $A$ bold stroke for a wife (1718), ibid., vol. 3, pp. 203-64, on p. 251.

59 Junius, 'The Air-Pump', Gentleman's Mag., 1740, 10: 194. For Domitian's cruelty cf. Suetonius, Lives of the Caesars, Domitian, 3 and 10-15.
} 


\section{Literary responses to animal experimentation}

air-pump next on his courtiers. Although the poem focused on the cruelty of animal experiments, this was not yet a serious concern.

Seen as a whole, the responses of Centlivre, Addison, Akenside, and "Junius" mark a transitional period. Writers still joked about the alleged uselessness of the virtuosi's animal experiments. However, the element of cruelty began to be perceived by them as well. To elucidate the background to this broadened view, the general topic of cruelty to animals in eighteenth-century British literature has to be considered.

THE SUFFERING OF THE BRUTE CREATION: MEN OF LETTERS ON CRUELTY AND KINDNESS TO ANIMALS

Significantly, it was Richard Steele, friend of both Addison and Mrs Centlivre, ${ }^{60}$ who in 1710, in the Tatler, took to the pen to attack the popular blood sports of cock-throwing, cock- and dog-fighting, bull-baiting, and bear-baiting. The cruelty of such entertainments, he warned, would make the British appear "barbarous" in the eyes of other nations. Steele appealed to his countrymen's conscience, insisting that the "virtues of tenderness, compassion and humanity, are those by which men are distinguished from brutes, as much as by reason itself". The killing of "innocent animals" was allowable only for the three purposes of human "safety", "convenience", and "nourishment". Otherwise it had to be looked upon as "a great piece of cruelty, if not a kind of murder". 61 Steele's attitude towards animals and animal suffering reflected contemporary educated opinion about man's relationship to the animal world. On the one hand, his view was traditionally anthropocentric, rooted in the Judeo-Christian belief that man, uniquely endowed with reason, had been given dominion by God over all other creatures. ${ }^{62}$ On the other hand, he was indebted to the ideal of a compassionate and benevolent "Man of Feeling", which at this time had fully emerged from the altruistic teachings of seventeenth-century Latitudinarian clergymen. ${ }^{63}$ By now "General Kindness" was beginning to overflow the borders of human kinship to cover also the irrational "brute creation". 64 Accordingly, in 1709, Steele confessed in the Tatler that he was moved to tears of pity by the death of a hunted deer, and, in another issue of the same year, he condemned the "perverse temper" of a boy tormenting birds. ${ }^{65}$

\footnotetext{
${ }^{60}$ See Centlivre, op. cit., note 52 above, 'To the World', p. xii; Bowyer, op. cit., note 53 above, pp. 41, 97-8, 119.

${ }^{61}$ Richard Steele, 'The Tatler No. 134, February 16, 1709-10', in op. cit., note 35 above, vol. 3, pp. 109-14. For further remarks by Steele on brutal pastimes at the London Bear Garden in Hockley in the Hole see 'The Tatler No. 28, June 14, 1709, No. 31, June 21, 1709', ibid., vol. 1, pp. 230-7, 254-62, and 'The Spectator No. 141, August 11, 1711' in op. cit., note 37 above, vol. 2, pp. 56-9; on the same topic see also John Gay, 'Trivia; or the art of walking the streets of London', in The poetical, dramatic and miscellaneous works of John Gay, 6 vols., London, 1795, repr. New York, AMS Press, 1970, vol. 2, pp. 133-95, p. 166.

$62 \mathrm{Cf}$. Thomas, op. cit., note 2 above, pp. 17-50.

${ }^{63}$ Cf. R. S. Crane, 'Suggestions towards a genealogy of the "Man of Feeling", J. Engl. Lit. Hist., 1934, 1: 205-30.

64 Cf. Cecil A. Moore, 'Shaftesbury and the ethical poets in England, 1700-1760', Publ. Mod. Lang. Ass., 1916, 24: 264-325, on p. 298; Harwood, op. cit., note 2 above, p. 139; Thomas, op. cit., note 2 above, pp. $175-6$.

65 Steele, 'The Tatler No. 68, September 15, 1709, No. 112, December 27, 1709', in op. cit., note 35 above, vol. 2, pp. 135-43, 410-15.
} 
In the same vein Alexander Pope contributed in 1713 to Steele's periodical the Guardian a humanitarian, though scholarly essay 'Against Barbarity to Animals' ${ }^{66}$ To the cruelties already castigated by Steele he added abuses in slaughtering. Using classical authority against "Barbarity", Pope quoted Plutarch's notion that "Humanity may be extended thro' the whole Order of Creatures, even to the meanest", 67 as well as several lines from Ovid's Metamorphoses, in which Pythagoras, out of a belief in metempsychosis, praises vegetarianism and denounces animal slaughtering as leading to homicide. ${ }^{68}$ Moreover, Pope invoked the authority of the Old Testament, when he cited Jonah 4:11 as an illustration of God's compassion to brutes, and Deut. 22:6-7 as a holy prescript for their considerate treatment. ${ }^{69}$ Man only has a right to destroy the "mortal" and "noxious" beasts, the poet concluded. To the subservient domestic animals, however, man even owes a degree of gratitude, and the life of those animals which were "neither of Advantage or Prejudice to us" should generally be spared. ${ }^{70}$

By the middle of the eighteenth century such kindness to animals had become fully incorporated into the moral ideals of British writers. ${ }^{71}$ For instance, Henry Fielding in his Tom Jones (1749) characterized the virtue and benevolence of Sophia Western, the great love of his hero, by her care for the horses drawing the stage-coach. ${ }^{72} \mathrm{He}$ apparently alluded to Prov. 12:10, which teaches that "a righteous man regardeth the life of his beast". Moreover, the assumption that those who are kind to animals will show mercy to men seems to be illustrated. Tom Jones himself, whose compassion and charity is repeatedly exemplified in the novel, was similarly described as thoughtful to the saddle-horses, though here Fielding gave philosophical reasons:

... for he [Jones] by no means agreed with the Opinion of those who consider Animals as mere Machines, and when they bury their Spurs in the Belly of their Horse, imagine the Spur and the Horse to have an equal Capacity of feeling Pain. ${ }^{73}$

Of course, this was a blow struck against the Cartesians, who-following their master's Discours de la méthode $(1637)^{74}$-had developed the radical view that animals were soulless, unfeeling machines, incapable of suffering pain. The controversy over the "beast-machine" had elevated the question of the nature and

\footnotetext{
${ }^{66}$ Alexander Pope, 'Against barbarity to Animals, The Guardian No. 61, May 21, 1713', in Norman Ault (ed.), The prose works of Alexander Pope, vol. 1, The earlier works, 1711-1720, Oxford, Basil Blackwell, 1936, pp. 107-14.

${ }^{67}$ Ibid., p. 111; cf. Plutarch, Life of Cato, 5.

68 See Pope, op. cit., note 66 above, pp. 107, 112; cf. Ovid, Metamorphoses, xv, 106-7, 116-24, 463-7.

${ }^{69}$ See Pope, op. cit., note 66 above, pp. 112-13.

${ }^{70} \mathrm{Cf}$. ibid., p. 113. For Pope's critical attitude towards hunting see also his poem 'Windsor-Forest' (1713) in Alexander Pope, Pastoral poetry and an essay on criticism, ed. E. Audra and Aubrey Williams, London, Methuen, New Haven, Yale University Press, 1961, pp. 148-94, on pp. 161-2.

71 Cf. Harwood, op. cit., note 2 above, pp. 180-222; de Levie, op. cit., note 2 above, pp. 61-76.

72 Henry Fielding, Tom Jones, ed. Sheridan Baker, New York and London, W. W. Norton, 1973, pp. 408-9.

${ }^{73}$ Ibid., p. 503.

74 The passages relevant to this issue are in René Descartes, Discours de la méthode, ed. Lüder Gäbe, Hamburg, Felix Meiner, 1960, pp. 90-7.
} 


\section{Literary responses to animal experimentation}

soul of animals to one of the major problems of seventeenth- and eighteenth-century philosophy. ${ }^{75}$ Zealous Cartesians were actually known for their callousness towards animals. ${ }^{76}$ In contemporary British literature, however, the doctrine of the "beastmachine" was in most instances rejected or derided. It was entirely contrary to common sense and everyday experience with animals. ${ }^{77}$ Butler, Shadwell, Brown, Centlivre, and Swift ridiculed the Cartesians' mechanistic view, while Addison, Steele, and Pope believed that animals were feeling creatures that were guided by divine instinct. ${ }^{78}$ Pope even attributed a rational soul to some higher animals such as dogs. Yet, it is also clear from this list of writers that not all of those who rejected the Cartesian "beast-machine" view necessarily had sympathy for animals or compassion for animal suffering. Fielding's causal connection of anti-Cartesianism with love for animals, as suggested by the character of Tom Jones, is merely one of several possible explanations for kindness to the "brute creation". Religious and moral motives, as well as personal sensibilities, were probably more common.

About ten years later, in 1760, Oliver Goldsmith, in one of his Chinese letters, sarcastically stated that a compassionate attitude towards animals had already become fashionable in the genteel world. Looking at British manners through the eyes of a "Chinese philosopher, Residing in London", the essayist observed:

The better sort here pretend to the utmost compassion for animals of every kind; to hear them speak, a stranger would be apt to imagine they could hardly hurt the gnat that stung 'em; they seem so tender, and so full of pity, that one would take them for the harmless friends of the whole creation; the protectors of the meanest insect or reptile that was privileged with existence. ${ }^{79}$

Goldsmith sharply contrasted these pretensions with his countrymen's passion for a good meat diet. Though he acknowledged that human beings were "born to govern the brute creation", he felt that meat eating had made them tyrants. He sympathized with vegetarianism and hailed the "simple, honest bramins of the east" whose belief in the transmigration of souls forbade the killing of animals, and he illustrated this

\footnotetext{
${ }^{75}$ See Leonora Cohen Rosenfield, From beast-machine to man-machine-the theme of animal soul in French letters from Descartes to La Mettrie, New York, Oxford University Press, 1940; Hastings, op. cit., note 49 above, pp. 19-63.

76 See Maehle and Tröhler, op. cit., note 4 above, pp. 26-8.

${ }^{77}$ Cf. Wallace Shugg, 'The Cartesian Beast-Machine in English literature (1663-1750)', J. Hist. Ideas, 1968, 29: 279-92.

${ }^{78}$ See Butler, op. cit., note 16 above, pp. 30-1; Shadwell, op. cit., note 24 above, p. 11; Brown, 'To Monsieur C-, upon the Cartesian philosophy', in op. cit., note 34 above, vol. 1, pp. 327-8; Centlivre, op. cit., note 52 above, pp. 218-19; Swift, op. cit., note 38 above, p. 103; Addison, 'The Spectator No.120, July 18, 1711, No. 121, July 19, 1711', in op. cit., note 37 above, vol. 1, pp. 489-97; Steele, 'The Tatler No. 112, December 27, 1709', in op. cit., note 35 above, vol. 2, pp. 410-15; Alexander Pope, An essay on man, ed. Maynard Mack, London, Methuen, 1950, pp. 43, 99-103. The Cartesian concept of animal automata was also ridiculed by the "Scriblerus Club": see Charles Kerby-Miller (ed.), Memoirs of the extraordinary life, works, and discoveries of Martinus Scriblerus-written in collaboration by the members of the Scriblerus Club John Arbuthnot, Alexander Pope, Jonathan Swift, John Gay, Thomas Parnell, and Robert Harley, Earl of Oxford, New York, Russell \& Russell, 1966, p. 141.

${ }^{79}$ Oliver Goldsmith, 'Letter XV. Against cruelty to animals. A story from the Zendevest of Zoroaster', in Collected works, 5 vols., ed. Arthur Friedman, vol. 2, The citizen of the world, Oxford, Clarendon Press, 1966 , pp. $66-8$, on p. 66.
} 


\section{Andreas-Holger Maehle}

doctrine by a Zoroastrian saga in which a man's carnivorous gluttony is severely punished in his after-life. ${ }^{80}$

Such references to the Brahman or Pythagorean doctrine of metempsychosis and its consequent vegetarianism were not unusual. ${ }^{81}$ Steele and Pope made use of it in the context of man's treatment of animals, and John Gay in his poem 'Trivia' (1716) had imagined how a coachman's soul would reincarnate in a "hackney horse" to atone for former brutalities. ${ }^{82}$ Moreover, oriental nations in general were held to deal with animals more gently than occidental ones. The humanity shown by the "Turk" in this respect was praised both by Pope and Steele. ${ }^{83}$ The growing Western sensitivity to animal suffering, however, as displayed in British literature, was becoming equally pronounced. Goldsmith himself disapproved of the innumerable killings of harmless, faithful, and obedient dogs which, because they were suspected to be rabid, were destroyed by a mob in the summer of $1760 .{ }^{84}$ Earlier that year, the theme of sympathy with animals had been carried to its literary extreme in a novel which Goldsmith, however, criticized for its "pertness". 85 In Tristram Shandy Laurence Sterne told the story of Uncle Toby, who was of such a "peaceful, placid nature" that he did not have the heart to kill a fly which had "tormented him cruelly all dinner-time". Having finally caught the insect in his hand Uncle Toby shows mercy to the little tormentor:

- I'll not hurt a hair of thy head: - Go, says he, lifting up the sash, and opening his hand as he spoke, to let it escape; - go poor Devil, get thee gone, why should I hurt thee? - This world surely is wide enough to hold both thee and me. ${ }^{86}$

Sterne made sure that this "lesson of universal good-will" was duly noticed by having an index finger printed in front of the sentence: "This is to serve for parents and governors instead of a whole volume upon the subject." 87 Indeed, to teach children kindness to animals became a major pedagogical concern in the second half of the eighteenth century, as can be inferred from such contemporary children's stories as the Fabulous histories designed for the instruction of children respecting their treatment of animals (1786) by Mrs Sara Trimmer (1741-1810) and A father's instructions (1775) by Thomas Percival (1740-1804). ${ }^{88}$ The latter, a Manchester

${ }^{80} \mathrm{Cf}$. ibid., pp. $66-8$.

${ }^{81}$ Cf. de Levie, op. cit., note 2 above, pp. 92-9; see also Narhar Kashinath Gharpure, Tierschutz, Vegetarismus und Konfession (eine religions-soziologische Untersuchung zum englischen 17. und 18. Jahrhundert), Munich, Hohenhaus, 1935.

${ }^{82}$ Cf. Steele, 'The Tatler No. 134, February 16, 1709-10', in op. cit., note 35 above, vol. 3, pp. 109-13, on p. 109; Pope, op. cit., note 66 above, p. 112; Gay, op. cit., note 61 above, p. 158.

${ }^{83}$ Cf. Steele, op. cit., note 35 above, vol. 3, pp. 110-11; Pope, op. cit., note 66 above, p. 111.

84 Goldsmith, 'Letter LXIX. The fear of mad dogs ridiculed', in op. cit., note 79 above, pp. $285-90$.

${ }^{85}$ Idem, 'Letter LIII. The absurd taste for obscene and pert novels, such as Tristram Shandy, ridiculed', ibid.. pp. 221-5.

${ }^{86}$ Laurence Sterne, Tristram Shandy, ed. Howard Anderson, New York and London, W. W. Norton, 1980 , p. 80.

${ }^{87}$ Ibid., p. 81.

${ }^{88}$ Cf. Sara Trimmer, Histoires fabuleuses, destinées à l'instruction des enfants dans ce qui regarde leur conduite envers les animaux, traduites de l'Anglois . . sur la seconde édition, par M. D. D. S. G., 2 vols., Geneva, Dufart, Paris, Barrois, 1789; Thomas Percival, 'A father's instructions', in The works, literary, 


\section{Literary responses to animal experimentation}

physician and writer, supplied various tales for children-"adapted to different periods of life"-against cruelty to insects, the taking of bird's nests, and against maltreatment of dogs and horses, all "designed to promote the love of virtue". ${ }^{89}$

Thus, in the course of the eighteenth century, British men of letters increasingly showed compassion for animals and their suffering and censured the human cruelty revealed in almost every instance of blood sports and hunting parties, in the streets and in the slaughter-house, and in children's play. ${ }^{90}$ The underlying assumption was that those who are kind to animals would also be kind to human beings, and, conversely, that cruelty to animals would lead to cruelty to men. ${ }^{91}$ William Hogarth illustrated this view in his moralizing series of engravings The four stages of cruelty. From 1751 onwards his prints popularized the lesson of Tom Nero, who starts as a juvenile tormentor of animals and ends as a murderer who is hanged and finally dissected in the anatomical theatre. ${ }^{92}$ The cruelty involved in animal experiments was noted by Centlivre, Addison, Akenside, and "Junius"; but were the experimentalists guilty of wanton cruelty? Evelyn's attitude is quite revealing in this regard. Whereas he had sharply condemned blood sports in his diary, he had been ready to accept, though reluctantly, even very invasive animal experimentation like that of Hooke. ${ }^{93}$ Or, as Isaac Barrow, the later mathematician and divine, had put it in an address at Cambridge University in 1654, vivisection could be seen as a "most innocent cruelty, and easily excusable ferocity", if the scientific purposes were only taken into account. ${ }^{94}$

\section{"BARBARITIES": ANIMAL EXPERIMENTATION UNDER OPEN ATTACK}

About a hundred years after Barrow's speech, however, it was precisely the Cambridge enthusiasm for animal dissections ${ }^{95}$ that was attacked in the successful novel The history of Pompey the Little or the life and adventures of a lap-dog (1st ed. 1751). ${ }^{96}$ Its author Francis Coventry (1725-54), the young vicar of Edgware near London, knew what he wrote about, for he had graduated from Magdalene College, Cambridge. Modelled on Fielding's Tom Jones, his novel gave a satirical picture of contemporary British life, characters and manners by following the lap-dog Pompey

moral, and philosophical, 2 vols., London, J. Johnson, 1807, vol. 1, pp. 1-377. See also Harwood, op. cit., note 2 above, pp. 250-9; Turner, op. cit., note 2 above, pp. 76-83.

${ }^{89}$ Cf. Percival, op. cit., note 88 above, pp. 12-16, 26-7, 62-7.

${ }^{90}$ For further examples see the works cited in note 2 above.

${ }^{91}$ See also Maehle and Tröhler, op. cit., note 4 above.

${ }^{2}$ Cf. Franz Kottenkamp (ed.), William Hogarth's Zeichnungen . . Mit der vollständigen Erklärung derselben von G. C. Lichtenberg, 2 vols., Stuttgart, Rieger, 1857-8, vol. 2, pp. 527-40.

${ }_{93}$ Cf. note 44 above and de Beer, op. cit. note 14 above, vol. 3, pp. 491-2, 549. In 1645 Evelyn had experimented on dogs himself, exposing them to the poisonous vapours of an Italian cave; see ibid., vol. 2, pp. 339-40.

94 Cf. Isaac Barrow, 'Oratio ad Academicos in Comitiis', in The theological works, 9 vols., ed. Alexander Napier, Cambridge, University Press, 1859, vol. 9, pp. 35-47, on p. 46; see also Percy H. Osmond, Isaac Barrow - his life and times, London, Society for Promoting Christian Knowledge, 1944, p. 40.

${ }^{95} \mathrm{Cf}$. Clark-Kennedy, op. cit., note 4 above, pp. 14-18; Robert Theodore Gunther, Early science in Cambridge, London, Dawsons, 1969, pp. 303-4.

${ }^{96}$ Francis Coventry, The history of Pompey the Little or the life and adventures of a lap-dog, ed. Robert Adams Day, London, New York, and Toronto, Oxford University Press, 1974. 
on a long and varied journey from master to master ${ }^{97}$ In the revised third edition of 1752 Coventry included an episode in which Pompey falls into the hands of a medical student who, before leaving to take up practice, wants to crown his university career by vivisecting a dog in the presence of his fellow students to unveil the secrets of the "iliac passion" (i.e., colic). ${ }^{98}$ "AND here, good-natured reader, I am sure it moves thy compassion to think that poor Pompey, after suffering already so many misfortunes, must at last be dissected alive to satisfy a physician concerning the peristaltic motion of the guts", Coventry commented at this point in the ironical manner of his ideal Fielding. ${ }^{99}$ Though Pompey finally escapes from this terrible fate, Coventry uses the scene for a witty digression on dogs, doctors, and vivisection:

\begin{abstract}
A DOG might have been the emblematic animal of Esculapius or Apollo, with as much propriety as he was of Mercury; for no creatures I believe have been of more eminent service to the healing tribe than dogs. Incredible is the number of these animals, who have been sacrificed from time to time at the shrines of physic and surgery. Lectures of anatomy subsist by their destruction; Ward (says Mr. Pope) tried his drop on puppies and the poor; and in general all new medicines and experiments of a doubtful nature are sure to be made in the first place on the bodies of these unfortunate animals. ${ }^{100}$
\end{abstract}

Coventry's critical attitude towards animal experimentation probably reflected a then commonly-held lay opinion, namely that the physiological knowledge derived from vivisection is "supplemental, and as many think, superfluous". ${ }^{101}$ The cruelty of vivisection was undoubtedly an issue to him. Equally, he castigated children's cruelty to animals, but he also derided ladies pampering their lap-dogs. ${ }^{102}$ Moreover, he satirized the contemporary learned debate on the philosophical problem of animal souls, ${ }^{103}$ and the jurists' dispute about the legal status of pets as opposed to ferae naturae, just as Fielding had done in Tom Jones. ${ }^{104}$ Coventry's pleas against the mistreatment of animals surely were not those of an ardent animal lover. Rather, as a contemporary reviewer of Pompey the Little observed,

He laughs at the world, without doing it the honour to be angry with it. His lashes, however smart, carry with them rather the marks of a benevolent correction, than of the spleen of misanthropy. ${ }^{105}$

\footnotetext{
${ }^{97}$ Cf. ibid., Introduction; see also William Scott, 'Francis Coventry's "Pompey the Little", 1751 and 1752', Notes and Queries, 1968, 15: 215-19; Toby A. Olshin, 'Pompey the Little: a study in Fielding's influence', Rev. Lang. Vivantes, 1970, 36: 117-24.

${ }_{98}$ Cf. Coventry, op. cit., note 96 above, pp. 184-6.

99 Ibid., p. 186.

100 Ibid., p. 185. For Pope's remark on Ward, see note 115 below.

101 Cf. Coventry, op. cit., note 96 above, p. 185.

${ }^{102}$ See ibid., pp. 22-9, 48-50, 200-1; on lap-dogs see also Addison, 'The Tatler No. 121, January 17 , $1709-10$, in op. cit., note 35 above, vol. 3 , pp. 39-43.

${ }^{103}$ See Coventry, op. cit., note 96 above, pp. 39-40, 169-72.

104 See ibid., pp. 198-9; cf. Fielding, op. cit., note 72 above, pp. 121-4.

105 [John Cleland], 'Art. XLV. The history of Pompey the little, or the life and adventures of a lap-dog', Monthly Rev., 1751, 4: 316-17, on p. 317.
} 


\section{Literary responses to animal experimentation}

But Alexander Pope was an actual zoophile, whose literary response to vivisection expressed a very serious concern for the suffering of experimental animals.

Pope was a dog-fancier who grew up in a dog-loving family and in the course of his life was the owner of at least four dogs, each called Bounce. ${ }^{106}$ One of these Bounces was included in a portrait of Pope by Jonathan Richardson (1665-1745), ${ }^{107}$ and the last two were immortalized in their master's poetry. 'Bounce to Fop' featured Bounce the bitch, one of whose puppies Pope soon had the honour to give away to the Prince of Wales. ${ }^{108}$ The last verses the poet presumably ever penned were an epitaph for the male Bounce which he finally had to commit to the care of his friend Lord Orrery and whose death in April 1744 preceded his master's by only a few weeks. 109

In addition to Pope's general advocacy of a humane treatment of animals, one has to keep in mind his love for dogs in order to understand the poet's verdict on vivisection. He pronounced it in January 1744, in one of those conversations with his friend Joseph Spence which have been preserved in the latter's Observations, anecdotes, and characters, of books and men (1st ed. 1820). ${ }^{110}$ Its immediate cause was the well-known animal experiments investigating blood pressure and blood circulation carried out by the Reverend Stephen Hales (1677-1761), curate of Teddington. ${ }^{11}$ Pope had become a neighbour of Hales when he moved to Twickenham at the end of 1718 . Spence started the remarkable dialogue:

'I shall be very glad to see Dr. Hales, and always love to see him; he is so worthy and good a man.'

Yes he is a very good man, only-I'm sorry-he has his hands imbrued with blood [Pope replied].

'What, he cuts up rats?'

Aye, and dogs too! (and with what emphasis and concern he spoke it.) Indeed, he commits most of these barbarities with the thought of its being of use to man. But how do we know that we have a right to kill creatures that we are so little above as dogs, for our curiosity, or even for some use to us? ${ }^{12}$

According to Pope, neither the improvement of physiological knowledge nor conceivable medical benefits were reasons sufficient to justify vivisection. In fact, the

106 Cf. Joseph Spence, Observations, anecdotes, and characters of books and men collected from conversation, 2 vols., ed. James M. Osborn, Oxford, Clarendon Press, 1966, vol. 2, pp. 629-30; see also Norman Ault, New light on Pope with some additions to his poetry hitherto unknown, London, Methuen, 1949, pp. 337-50.

107 See ibid., frontispiece.

108 Alexander Pope, 'Bounce to Fop. An heroick epistle from a dog at Twickenham to a dog at Court', in Minor poems, ed. Norman Ault, compl. by John Butt, London, Methuen, New Haven, Yale University Press, 1954, pp. 366-71; see also Gentleman's Mag., 1736, 6: 286, and London Mag., May 1736, pp. 271-2.

109 "Ah Bounce! ah gentle Beast! why wouldst thou dye, When thou hadst Meat enough, and Orrery?": 'Pope to the Earl of Orrery, 10 April 1744', in George Sherburn (ed.), The correspondence of Alexander

Pope, 5 vols., Oxford, Clarendon Press, 1956, vol. 4, pp. 517-18, on p. 517.

10 Spence, op. cit., note 106 above.

111 See Stephen Hales, Statical essays: containing haemastaticks, London, Innys, Manby, and Woodward, 1733. For a discussion of these experiments see Clark-Kennedy, op. cit., note 4 above, pp. 22-42; Allan and Schofield, op. cit., note 4 above, pp. 48-64.

112 Spence, op. cit., note 106 above, vol. 1 , p. 118 . 
dog-fancier's anger was quite different from the mockery of the Restoration "Wits and Railleurs" or from the satirical lashes Coventry intended as "a benevolent correction". Yet, Pope's criticism of Hales's practice and (supposed) over-estimation of the utility of vivisection did not go together with a personal condemnation of the experimentalist. On the contrary, the characterization "a very good man" was preceded, in Pope's 'Epistle to a Lady' (1735), by "plain Parson Hale [sic]", ${ }^{113}$ and only a month before the quoted conversation took place, Hales had been a witness to Pope's will. ${ }^{114}$ However, Pope had already stated in his 'Epistle to Cobham' (1734) that "following life thro' creatures you dissect, You lose it in the moment you detect". 115

Pope's philosophical position as to the souls of animals, especially dogs, must also be taken into account. The sequel to the conversation with Spence quoted above reveals why the poet had placed man only "little above" them:

'I used to carry it too far; I thought they [dogs] had reason as well as we' [said Spence].

So they have, to be sure [replied Pope]. All our disputes about that are only a dispute about words. Man has reason enough only to know what it is necessary for him to know, and dogs have just that too.

'But then they must have souls too, as unperishable in their nature as ours. And as our arguments from the actions of our own souls must hold equally for them, if they have any such thing as ideas or thoughts raised within them, where would be the harm to us in allowing them immortality too?'

None at all. ${ }^{116}$

A hundred years earlier, this inclination to attribute an immortal thinking soul to animals might well have been denounced as heresy, for it contradicted the Christian dogma about man, God's image, who was separated from the "brute creation" by an unbridgeable gap because of his unique faculty of reason and the privilege of an unperishable soul. ${ }^{117}$ But in Pope's more secularized times the rigidity of such anthropocentrism already seems to have relaxed. The more naturalistic concept of a Great Chain of Being, which had its origins in ancient Greek philosophy, connected all forms of living beings from the lowest to the highest. It attained its widest

113 Alexander Pope, 'Epistle II. To a Lady of the Characters of Women', in Epistles to several persons (moral essays), ed. F. W. Bateson, London, Methuen, New Haven, Yale University Press, 1951, pp. 45-71, on p. 64.

114 Cf. Clark-Kennedy, op. cit., note 4 above, p. 56.

115 Pope, 'Epistle I. To Sir Richard Temple, Lord Viscount Cobham', in op. cit., note 113 above, pp. 15-36, on p. 18. Other contemporary "experiments" attracted Pope's attention: in 1733 he pointed to the depraved character of the imprisoned John Ward, MP: "During his confinement, his amusement was to give poison to dogs and cats, and see them expire by slower or quicker torments."; cf. Pope, 'Epistle III. To Allen Lord Bathurst', ibid., pp. 81-121, on p. 83. Pope's sarcastic observation of 1737 that "Ward try'd on Puppies, and the Poor, his Drop"-later quoted by Coventry-referred to the quack doctor Joshua Ward (1685-1761), who had become famous for his panacea "pill and drop"; cf. Alexander Pope, Imitations of Horace, ed. John Butt, London, Methuen, New Haven, Yale University Press, 1953, p. 211; and Marjorie H. Nicolson, 'Ward's "Pill and Drop" and men of letters', J. Hist. Ideas, 1968, 29: 177-96.

116 Spence, op. cit., note 106 above, vol. 1, pp. 118-19.

117 Cf. Thomas, op. cit., note 2 above, pp. 30-6; John Passmore, 'The treatment of animals', J. Hist. Ideas, 1975, 36: 195-218. 
diffusion and acceptance in the course of the eighteenth century, and, via his famous 'Essay on Man' (1733), Pope was one of its leading advocates. ${ }^{118} \mathrm{He}$ even included mental faculties in his idea of a continuously ascending, or descending, gradation, thereby considerably narrowing the gap between man and brutes. ${ }^{119}$ This goes some way to explaining why Pope had strong reservations about Hales's animal experiments. To see someone killing or severely hurting "half-reas'ning" fellowcreatures, ${ }^{120}$ such as dogs, necessarily raised grave moral questions for the poet. Man's God-given superiority over brutes was not in doubt, but where lay the limits of human rights towards the lower creatures in the Great Chain of Being?

In summary, Pope's attitude to vivisection was influenced by both his personal love for animals, especially for dogs, and his philosophical opinion about the man-animal relationship. Together with his general sensitivity to animal suffering, which he shared with other eminent men of letters of his century, these elements produced an early, serious, and critical response to animal experimentation.

The contrast between Pope, the sensitive poet, and his neighbour Hales, the vivisecting scientist, made a lasting impression, for the Reverend Thomas Twining (1735-1804), who was born and grew up in Twickenham, still pointed to it in his poem 'The Boat', which he wrote several years after both Pope and Hales had died and he himself had settled in the parish of Fordham near Colchester in $1764 .^{121}$ Describing a boating trip up the Thames, Twining rhymed:

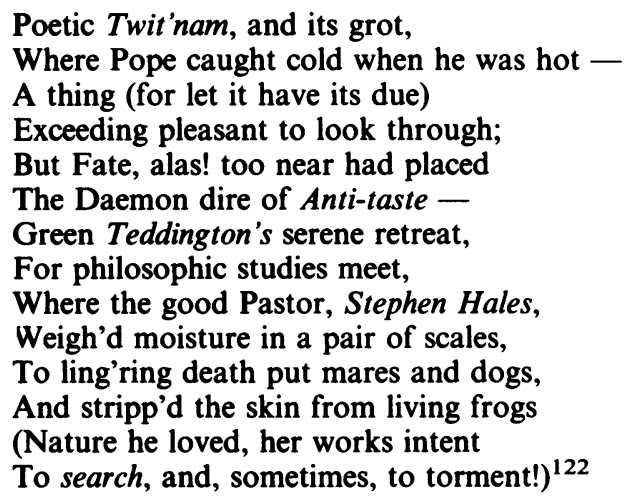

Obviously Twining, whose own old parsonage at Fordham was depicted in the poem as "undermined by rats" and surrounded by "Ducks, chickens, goslings, pigs, and

118 Pope, op. cit., note 78 above, pp. 44-5. Cf. Arthur O. Lovejoy, The great chain of being, Cambridge, Mass., and London, Harvard University Press, 1964, pp. 183-207; Bernhard Fabian, 'Newtonische Anthropologie: Alexander Popes Essay on Man', in B. Fabian, W. Schmidt-Biggemann, and R. Vierhaus (eds.), Deutschlands kulturelle Entfaltung. Die Neubestimmung des Menschen, Munich, Kraus, 1980, pp. 117-33.

${ }_{119}$ Cf. Pope, op. cit., note 78 above, pp. 41-4.

120 Cf. ibid., p. 43.

121 Thomas Twining, 'The Boat', in Recreations and studies of a country clergyman of the eighteenth century being selections from the correspondence of the Rev. Thomas Twining, M.A., ed. Richard Twining, London, John Murray, 1882, pp. 240-5.

122 Ibid., pp. 242-3. 
cows", 123 disapproved of Hales's painful animal vivisections, though he appeared ready to acknowledge the "good Pastor's" scientific motives. Now that the cruelty involved in animal experiments had been brought into focus by men of letters, the question of its justifiability attracted attention.

No less a man than Samuel Johnson carried on the moral criticism of animal experimentation. In 1758 he published a highly emotional denunciation in his much-read weekly paper the Idler (1758-60). ${ }^{124}$ Johnson started in the mode of the familiar, more or less good-natured "virtuoso-satire". The microscopist, the botanist, the physicist, and the chemist are ridiculed. ${ }^{125}$ But then, abruptly leaving the satirical level, Johnson made an important distinction:

The Idlers that sport only with inanimate nature may claim some indulgence; if they are useless they are still innocent: but there are others, whom I know not how to mention without more emotion than my love of quiet willingly admits. ${ }^{126}$

This is followed by an expression of anger at the practice of animal experimentation:

Among the inferiour professors of medical knowledge, is a race of wretches, whose lives are only varied by varieties of cruelty; whose favourite amusement is to nail dogs to tables and open them alive; to try how long life may be continued in various degrees of mutilation, or with the excision or laceration of the vital parts; to examine whether burning irons are felt more acutely by the bone or tendon; and whether the more lasting agonies are produced by poison forced into the mouth or injected into the veins. ${ }^{127}$

Like Addison in the Spectator, Johnson apologized to the readers of the Idler for having offended "the sensibility of the tender mind with images like these", thus implying a sensitivity to animal suffering among the educated public of his days. He only dared to quote "such cruelties", since they were anyhow "published every day with ostentation" and since he himself would only mention them "with abhorrence". ${ }^{128}$

Who were these experimentalists who filled Johnson with such indignation? The "burning irons" applied to the bones and tendons of living animals may refer to the contemporary controversy over sensibility and irritability between Albrecht von Haller and Robert Whytt. ${ }^{129}$ Ironically enough, it was Richard Brocklesby (172297), Johnson's physician and close friend, who had just published the results of his

\footnotetext{
123 Ibid., p. 245.

124 Samuel Johnson, 'The Idler No. 17, 5 August 1758' in idem, The Idler and The Adventurer, ed. W. J. Bate, J. M. Bullit, and L. F. Powell, New Haven, Yale University Press, 1963, pp. 53-6.

${ }_{125}$ Cf. ibid., p. 54. For Johnson's “virtuoso-satire” see also 'The Idler No. 31, 18 November 1758', ibid., pp. 95-8; Samuel Johnson, 'The Rambler No. 82, 29 December 1750, No. 177, 26 November 1751, No. 199, 11 February 1752', in idem, The Rambler, 3 vols., ed. W. J. Bate and Albrecht B. Strauss, New Haven and London, Yale University Press, 1969, vol. 2, pp. 64-70, vol. 3, pp. 168-72, $271-6$.

126 Idem, op. cit., note 124 above, p. 55.

127 Ibid.

128 Cf. ibid.

${ }^{129} \mathrm{Cf}$. Albrecht von Haller, $A$ dissertation on the sensible and irritable parts of animals. Trans. from the Latin. With a Preface by M. Tissot, London, J. Nourse, 1755; Robert Whytt, 'Observations on the
} 


\section{Literary responses to animal experimentation}

own animal experiments on these lines. ${ }^{130}$ And the question whether drug testing on animals should be conducted by means of peroral administration or intravenous injection had been discussed by Browne Langrish in his Physical experiments upon brutes (1746). He performed several toxicological trials on dogs and horses with cherry-laurel. ${ }^{131}$ Richard Mead, otherwise highly esteemed by Johnson, had made the same kind of experiments, reporting on them, among many others, in his Mechanical account of poisons (1st ed. 1702), which by 1758 had passed through no fewer than fourteen editions. ${ }^{132}$

Johnson's wrath must also have been roused by the medical students' enthusiasm for animal vivisection. Whereas Coventry, the "benevolent corrector", had only satirized this practice, Johnson connected it with grave misgivings about the treatment of human patients:

... the anatomical novice tears out the living bowels of an animal, and stiles himself physician, prepares himself by familiar cruelty for that profession which he is to exercise upon the tender and the helpless, upon feeble bodies and broken minds, and by which he has opportunities to extend his arts of torture, and continue those experiments upon infancy and age, which he has hitherto tried upon cats and dogs. ${ }^{133}$

Both the general view that cruelty to animals will lead to cruelty to men and the more specific suspicion that animal experimentation will end in human experimentation-previously intimated in a satirical way by Shadwell, Centlivre, and "Junius"-were now explicitly stated by Johnson.

Johnson admitted that physiological knowledge might be increased a little by means of vivisection, but he saw no therapeutic benefit whatsoever. Yet, he was well informed about the experimentalists' justifications, which were essentially based on the argument of utility. ${ }^{134}$ In fact, Haller, Whytt, Brocklesby, Langrish, and

sensibility and irritability of the parts of men and other animals', in Physiological essays, Edinburgh, Hamilton, Balfour, and Neill, 1755, pp. 97-223. See also R. K. French, Robert Whytt, the soul, and medicine, London, Wellcome Institute of the History of Medicine, 1969, pp. 63-76; Heinz Hürzeler, Robert Whytt (1714-1766) und seine physiologischen Schriften, Zürcher Medizingesch. Abh., n. s., vol. 96, Zürich, Juris, 1973, pp. 59-69.

${ }^{130}$ Richard Brocklesby, 'An account of some experiments on the sensibility and irritability of the several parts of animals', Phil. Trans. R. Soc., 1755 (publ. 1756), 49: 240-5. A short summary of this article was given in Gentleman's Mag., 1756, 26: 617. On their friendship see Brian Hill, 'Doctor Johnson's doctor', Practitioner, 1964, 193: 812-15.

${ }_{131}$ Cf. Browne Langrish, Physical experiments upon brutes, London, C. Hitch, 1746, pp. 53-125.

132 Cf. Richard Mead, 'A mechanical account of poisons', in The medical works, 3 vols., Edinburgh, A. Donaldson and J. Reid, 1765, vol. 1, pp. 1-158, on pp. 137-41. See also 'A view of Dr. Mead's essay on poisons', Gentleman's Mag., 1745, 15: 255-60, 308-11. Mead's name was mentioned in the Idler, No. 17, though not with reference to his animal experiments'; cf. Johnson, op. cit., note 124 above, p. 55. For Johnson's high opinion of Mead see John Lawrence Abbott, 'Samuel Johnson and "The Life of Dr. Richard Mead"', Bull. John Rylands Libr., 1971, 54: 12-27. Abbott (ibid., p. 23) supposes that Johnson "had a hand" in the above-cited review of Mead's 'Mechanical account of poisons'.

133 Johnson, op. cit., note 124 above, p. 55.

134 Ibid., pp. 55-6: "What is alleged in defence of these hateful practices, every one knows; but the truth is, that by knives, fire, and poison, knowledge is not always sought, and is very seldom attained . . I I know not, that by living dissections any discovery has been made by which a single malady is more easily cured." 


\section{Andreas-Holger Maehle}

Mead-and also Hales-had all expressed the conviction that the results of their animal experiments would have considerable therapeutic consequences. The wish to benefit mankind by means of animal experimentation figured as a recurrent theme in their writings. ${ }^{135}$ In this way Haller and Brocklesby had even explicitly excused the cruelty of their vivisections. ${ }^{136}$

The actual extent of animal experimentation in eighteenth-century Britain has not yet been sufficiently well documented. It would surely be underestimated, however, by taking into account only the authors mentioned above. ${ }^{137}$ Still, it is true that in the time of Johnson unquestionable therapeutic advances from animal experiments were hard to perceive, and the optimistic view that some day the end, in the form of better cures for patients, would justify the means was not widely held among the general public, if Coventry's statement of 1752 can be trusted. ${ }^{138}$

In Johnson's view, animal experiments could not be excused. They were both virtually useless and, because they corrupted the physicians, potentially dangerous to man. Thus the essayist concluded:

It is time that universal resentment should arise against these horrid operations, which tend to harden the heart, extinguish those sensations which give man confidence in man, and make the physician more dreadful than the gout or stone. ${ }^{139}$

As this quotation shows, Johnson's attitude was essentially anthropocentric. The potential detrimental effects of cruelty to animals on the moral standards of man upset him, not the animals' suffering as such. Yet, as in the case of Pope, the vigour of Johnson's attack on vivisection makes it likely that his love for animals also was a factor. Pope's Bounces actually had a feline equivalent in Johnson's household: Hodge, the writer's pampered tom-cat, "for whom he himself used to go out and buy oysters, lest the servants having that trouble should take a dislike to the poor creature", as James Boswell remembered. ${ }^{140}$ However, Johnson did not go as far as Pope in attributing a rational, immortal soul to his pet, though he also disagreed with the Cartesians' opposite concept of the "beast-machine". ${ }^{141}$ For him, animals seemed "to have their minds exactly adapted to their bodies, with few other ideas than such as

$135 \mathrm{Cf}$. Haller, op. cit., note 129 above, p. 3; Whytt, op. cit., note 129 above, p. 100-1; Brocklesby, op. cit., note 130 above; Langrish, op. cit., note 131 above, pp. vii-xxii, 56-60, 120-5; Mead, op. cit., note 132 above, pp. 18-19; Hales, op. cit., note 111 above, pp. vii-viii, xvii-xxi.

${ }^{136}$ Cf. Haller, op. cit., note 129 above, p. 2; Brocklesby, op. cit., note 130 above, p. 240.

${ }^{137}$ For example, see also William and John Hunter, or William Cumberland Cruikshank, note 149 below.

138 See note 101 above. See also Karl E. Rothschuh, Physiologie-Der Wandel ihrer Konzepte, Probleme und Methoden vom 16. bis 19. Jahrhundert, Freiburg and Munich, Karl Alber, 1968, p. 28.

139 Johnson, op. cit., note 124 above, p. 56.

140 Cf. George Birkbeck Hill and L. F. Powell (eds.), Boswell's Life of Johnson, 6 vols., Oxford, Clarendon Press, 1934-50, vol. 4, p. 197. For further references to Johnson as an animal lover see Hester Lynch Piozzi, Anecdotes of the late Samuel Johnson, LL.D. during the last twenty years of his life, ed. Arthur Sherbo, London, New York, and Toronto, Oxford University Press, 1974, p. 109; William E. A. Axon, 'Dr. Johnson's sympathy for animals', Nation, 1908, 87: 231.

${ }^{141} \mathrm{Cf}$. Hill and Powell, op. cit., note 140 above, vol. 2, pp. 53-4; Johnson, 'The Idler No. 10, 17 June 1758 , in op. cit., note 124 above, pp. $32-6$. 


\section{Literary responses to animal experimentation}

corporal pain or pleasure impress upon them". ${ }^{142}$ Accordingly, he regarded most animal actions as being guided by instinct. ${ }^{143}$ Johnson's "fondness . . . for animals which he had taken under his protection", as Boswell related, probably has to be interpreted as part of his general humanitarian attitude, which corresponded to the contemporary ideal of "universal good-will". Thus Boswell listed Johnson's "indulgence with which he treated Hodge, his cat" among the proofs of the "real humanity and gentleness of his disposition", which also included the writer's love of children and his kindness to his servants. ${ }^{144}$ Quite characteristically, Johnson's sympathy for animals was expressed, too, in the case of slaughtering, where he was predominantly concerned with the lessening of pain. ${ }^{145}$

Johnson's befriending of animals may help to explain why he denounced animal experimentation so vehemently. Idiosyncrasies such as his dread of the sight of blood, and horror at the sight of bones, both reported by Boswell, should also be taken into account here. ${ }^{146}$ On the other hand, in the area of natural history, he acknowledged-at least theoretically-the scientific value of experimentation. Moreover, he enjoyed carrying out chemical experiments and revealed his understanding of the virtuosi and their pursuits. Clearly, Johnson did not oppose the experimental method as such. ${ }^{147}$ With regard to the particular practice of animal experimentation, however, he even repeated his vigorous attack in a note on Cymbeline, I.v.23, in his edition of Shakespeare's works (1765). Shakespeare's point, made about 150 years before Johnson's, was just the same: callous experimenting on animals prepares for cruelty to human beings. ${ }^{148}$ Still, Johnson could well be a personal friend of individual vivisectors, such as Brocklesby and Mead. ${ }^{149}$ In this respect, too, he resembled Pope.

Nevertheless, Johnson's criticism of animal experimentation was probably fiercer than any before. It seems to reflect the end of light-hearted satires on the subject:

\footnotetext{
142 Johnson, 'The Rambler No. 41, 7 August 1750', in op. cit., note 125 above, vol. 1, pp. 221-6, on p. 222.

${ }^{143}$ Cf. ibid., pp. 222-3; Hill and Powell, op. cit., note 140 above, vol. 2, pp. 95-6, 248-9; Johnson, 'The Idler No. 24, 30 September 1758', in op. cit., note 124 above, pp. 74-7.

144 Cf. Hill and Powell, op. cit., note 140 above, vol. 4, pp. 196-7.

145 Cf. ibid., vol. 4, pp. 248-50, vol. 5, pp. 246-7.

146 See ibid., vol. 4, p. 247, vol. 5, pp. 169, 327; see also Brown, op. cit., note 3 above, pp. 219-20.

147 See Hill and Powell, op. cit., note 140 above, vol. 1, pp. 140, 436, vol. 2, pp. 54-5, 155-6, 232-3, vol. 3, pp. 398-9; Johnson, 'The Rambler No. 83, 1 January 1751', in op. cit., note 125 above, vol. 2, pp. 70-6; idem, 'The Idler No. 88, 22 December 1759', in op. cit., note 124 above, pp. 273-5. See also Richard B. Schwartz, Samuel Johnson and the New Science, Madison, Milwaukee, and London, University of Wisconsin Press, 1971; J. R. Philip, 'Samuel Johnson as antiscientist', Notes Rec. R. Soc. Lond., 1974-5, 29: 193-203.

148 Arthur Sherbo (ed.), Johnson on Shakespeare, 2 vols., New Haven and London, Yale University Press, 1968 , vol. 2 , p. 881 .

${ }^{149}$ See notes 130 and 132 above. Also, Johnson recommended a pupil of William Hunter, the surgeon William Cumberland Cruikshank (1745-1800), who had experimented on rabbits in 1778, for the appointment as Professor of Anatomy at the Royal Academy in 1783. In his last days Johnson had himself treated by Cruikshank. It is not certain however, that Johnson actually knew about his surgeon's animal experiments, which were published only in 1797. Cf. William Cruikshank, 'Experiments in which, on the third day after impregnation, the ova of rabbits were found in the Fallopian tubes; and on the fourth day after impregnation in the uterus itself; with the first appearances of the foetus', Phil. Trans. R. Soc., 1797, 87: 197-214; Hill and Powell, op. cit., note 140 above, vol. 4, pp. 219-20, 239-40, 365,
} 


\title{
Andreas-Holger Maehle
}

mockery had given way to anger. Sensitivity to animal suffering had grown, and the cruelty involved in animal experiments had become a question of serious concern.

In 1775 Thomas Percival, later the author of Medical ethics (1803), ${ }^{150}$ dealt with this concern in his $A$ father's instructions, mentioned above. Among the tales that were directed against cruelty to animals he included one entitled 'Cruelty in Experiments'. ${ }^{151}$ Euphronius, the father, a friend of Dr Priestley (i.e., Joseph Priestley), is experimenting on the properties of various kinds of air. When he has prepared a glass of "mephitic water", 152 his son Alexis hurries in with a number of fishes which he has caught and kept alive. Knowing that the "fixed air" (i.e., carbon dioxide, in solution carbonic acid) in this kind of water is fatal for terrestrial animals, the boy urges his father to try the experiment upon the fishes. Euphronius yields to the "impatient curiosity" of his son and puts them into the water. Soon they are dropping lifeless to the bottom of the vessel. Surprise and joy sparkle in the eyes of Alexis. But then follows the "Father's Instruction":

\begin{abstract}
Beware, my son ... of observing spectacles of pain and misery with delight. Cruelty, by insensible degrees, will steal into your heart; and every generous principle of your nature will then be subverted. The philosopher, who has in contemplation the establishment of some important truth, or the discovery of what will tend to the advancement of real science, and to the good and happiness of mankind, may perhaps be justified, if he sacrifice to his pursuits the life or enjoyment of an inferior animal. But the emotions of humanity should never be stifled in his breast; his trials should be made with tenderness, repeated with reluctance, and carried no farther than the object in view unavoidably requires. Wanton experiments on living creatures, and even those, which are merely subservient to the gratification of curiosity, merit the severest censure. They degrade the man of letters into a brute; and are fit amusements only for the cannibals of New-Zealand. ${ }^{153}$
\end{abstract}

In real life, Percival and Priestley, who were friends, had studied "fixed air", for which Percival suggested several medicinal uses. ${ }^{154}$ The empirical foundations for his

399-400, 403; see also Macdonald Daly 'Quasi-anti-vivisection in the eighteenth century', forthcoming in Durham Univ. $J$.

${ }^{150}$ See Chauncey D. Leake (ed.), Percival's medical ethics, Huntington, NY, Robert E. Krieger, 1975; see also the editorial 'Thomas Percival (1740-1804) codifier of medical ethics', J. Am. med. Ass., 1965, 194: 1319-20, and Huldrych M. Koelbing, 'Die “Ärztliche Ethik” des Thomas Percival', Schweiz. med. Wschr., 1967, 97: 713-16.

151 Percival, op. cit., note 88 above, vol. 1, pp. 50-1.

152 In a footnote Percival defined "mephitic water" as "Water impregnated with fixed air, which is separated from chalk or pot-ash, by means of oil of vitriol, or any other acid": ibid., p. 50. This corresponds to the method of preparation described in Joseph Priestley, Directions for impregnating water with fixed air, London, J. Johnson, 1772, pp. 5-9, and in Thomas Percival, 'On the antiseptic and sweetening powers, and on the varieties of factitious air', in Essays medical and experimental, 2 vols., London, J. Johnson, B. Davenport, 1767-73, vol. 2, pp. 81-91, on pp. 87-8. See also Heinrich Buess, 'Joseph Black (1728-1799) und die Anfänge chemischer Experimentalforschung in Biologie und Medizin', Gesnerus, 1956, 13: 165-89.

153 Percival, op. cit., note 88 above, vol. 1, p. 51.

154 See Priestley, op. cit., note 152 above, pp. 18-21; Percival, 'On the medicinal uses of fixed air', in op. cit., note 152 above, vol. 2, pp. 71-80; idem, 'On the solution of stones of the urinary and of the gall bladder by water impregnated with fixed air', in Philosophical, medical, and experimental essays, London, J. Johnson, 1776, pp. 129-70. 


\section{Literary responses to animal experimentation}

recommendations, however, were chemical experiments and clinical experience. Though Percival, who was a Fellow of the Royal Society, had praised the value of experimentation for the progress of medicine, ${ }^{155}$ with regard to animal experiments he seems to have exercised restraint. When he and Priestley once exposed a mouse in a receiver to the very noxious vapours of white-lead paint, they hastened to save the animal's life, the mouse being "immediately withdrawn". ${ }^{156}$ And when Percival merely cited lethal injection experiments with tincture of cantharides, which had been performed on two dogs as early as 1692 by Giorgio Baglivi, he noted that they were "cruel". ${ }^{157}$ Thus Percival's conduct as a scientist was in keeping with the concern about animal experiments which he expressed as a man of letters.

Percival's main fear was the brutalizing effect of callousness to animals. Since the compassionate "Man of Feeling" was his pedagogical aim, young Alexis's character is presented as being endangered when "curiosity" makes him look at the experimental animals' suffering "with delight". Yet, the infliction of pain on animals is not only seen as a danger to the morals of children, but to the mature scientist's too. Strictly speaking, Percival intended to protect the experimentalists' moral standards rather than the experimental animals' life. Like Johnson, he shared the general, anthropocentric view that cruelty to animals leads to cruelty to men and applied this to the specific case of animal experimentation. Unlike Johnson, however, he showed a comparatively high regard for the scientific results and potential benefits of animal experiments, which, of course, may have been connected with the fact that he was a physician. Thus Percival's important distinction between beneficial, and therefore justifiable, experiments and those that were "wanton" or motivated by mere "curiosity" was essentially a calculus of utility. The "life or enjoyment" of animals and the "good and happiness of mankind" were weighed up. The result was not surprising in view of the author's anthropocentricity: the advantage of human beings outweighed that of brutes. ${ }^{158}$

Seen in this light, Percival's 'Cruelty in Experiments' was much more than an edifying children's tale. It was a fundamental piece of serious moral philosophy upon the subject of animal experimentation. Since the days of Butler, Shadwell, and the other "Wits and Railleurs", the literary responses had undergone a genuine change.

\section{CONCLUSIONS}

The general attitude of British men of letters towards the scientific method of

${ }_{155}^{15}$ Idem, op. cit., note 152 above, vol. 1, Preface, p. 3.

${ }^{156} \mathrm{Cf}$. idem, Observations and experiments on the poison of lead, London, J. Johnson, 1774, pp. 65-7. Similarly, Anna Laetitia Barbauld (1743-1825), who wrote, among other things, moralizing children's tales like Percival's, is said to have induced Priestley to exempt a mouse from experimentation with various gases by attaching her piteous poem 'The Mouse's Petition' to the animal's cage: Lucy Aikin (ed.), The works of Anna Laetitia Barbauld, 2 vols., London, Longman, 1825, vol. 1, pp. 35-8; see also Turner, op. cit., note 2 above, p. 78.

${ }^{157}$ See Percival, 'On the uses and operation of blisters', in op. cit., note 152 above, vol. 1, pp. 167-224, on p. 171; cf. Giorgio Baglivi, 'Dissertatio de usu et abusu vesicantium', in Opera omnia medico-practica et anatomica, 2 vols., ed. C. Gottlieb Kühn, Leipzig, Leopold Voss, 1827-8, vol. 2, pp. 344-68, on pp. 345-6.

${ }^{158}$ For the history of moral calculi see Louis I. Bredvold, 'The invention of the ethical calculus' in Jones, op. cit., note 6 above, pp. 165-80; for an eighteenth-century moral calculus of the specific problem of 
animal experimentation was a critical one during the century following the Royal Society's foundation. An unambiguous advocate has not been found among them. The nature and style of their criticism, however, varied. Although the different backgrounds of the individual authors have to be taken into account, a collective development of their responses can be sketched.

In the second half of the seventeenth and early eighteenth centuries mockery was the predominant reaction to the experimentalist's pursuits. Within the literary genre of "virtuoso-satire" the opinion that animal experiments were in practice useless was formed and perpetuated. The main objects of criticism were the scientist's supposed waste of time and money and his neglect of social duties. Exponents of this kind of satire, who did not express concern for the possible suffering of animals in experiments, were Butler, Shadwell, Brown, and Swift. In the first half of the eighteenth century, however, some of the satirists, namely Centlivre, Addison, Akenside, and "Junius", offered a broader criticism of the virtuosi, which included the element of cruelty in animal experimentation. Yet the satirical tradition of the Restoration period was still strong in the work of these authors. On the other hand, in the course of the eighteenth century, criticism of man's callousness to animals and pleas for a considerate treatment of the "brute creation" became a literary theme in the work of such writers as Steele, Pope, Gay, Fielding, Goldsmith, and Sterne, and were popularized in pedagogical literature by Percival and Trimmer. This development corresponded firstly to a growth of sensitivity to animal suffering among the educated public, secondly to the contemporary discussion about the nature of animals and their relationship to man, and thirdly to the preoccupation with the consequences of cruelty to animals for man's moral standards. Obviously, the issue of animal experimentation could not remain neutral under these circumstances. Thus around 1750 the cruelty involved in animal experiments became an object of literary attack. Whereas Coventry tried a "benevolent correction" with the "lashes" of satire, Pope spoke with "emphasis and concern" about the "barbarities" of vivisection (echoed by Twining years later), and Johnson was scandalized by the "race of wretches" that experimented upon living animals. The fact that Pope and Johnson were lovers of animals in their private lives must have figured in their attacks on animal experimentation. But their emotive comments fit the contemporary literary partiality for "kindness" to the "brute creation" too well to be dismissed as the result of mere over-sensitivity.

The example of Johnson furthermore seems to illustrate that in the second half of the eighteenth century the literary genre of "virtuoso-satire" had become inadequate for the subject of animal experimentation. He still could satirize in conventional terms the "Idlers that sport only with inanimate nature", but it was impossible for him to do the same with vivisectors. In fact, after Johnson, light-hearted satires in which animal experimentation was ridiculed in the spirit of Shadwell or Swift were rarely if ever

vivisection in German literature see Andreas-Holger Maehle, 'Der Literat Christlob Mylius und seine Verteidigung des medizinischen Tierversuchs im 18. und 19. Jahrhundert', Medizinhist. J., 1986, 21: $269-87$. 


\section{Literary responses to animal experimentation}

written. ${ }^{159}$ However, it has also to be considered that "virtuoso-satire" in general seemed to have vanished towards the end of the eighteenth century, making way for scientific realism in literature. ${ }^{160}$

Johnson's attacks show that the issue of animal experimentation had risen to a moral one that deserved serious attention, especially since the benefits seemed doubtful. Percival discussed the claim of benefit, essentially performing a moral calculus of utility. Unlike the early "Wits and Railleurs", Johnson and Percival did not repudiate the experimental method; it was its application to sensitive living beings that provoked their severe moral criticism.

Seen as a whole, a remarkable shift had taken place. Ridicule against any and all scientific undertakings, which naturally included animal experimentation, had been replaced by the moral argument precisely against this practice. Despite this change in the literary responses to animal experiments in the course of the seventeenth and eighteenth centuries a common element persisted, namely anthropocentricity. It made satirists look at the experimentalist, not at the animal, and it made serious critics look at the effects of cruelty on human morality, not at animal suffering as such. True anti-vivisectionism emerged only with the anthropomorphism of the Victorian age. ${ }^{161}$ Although Jeremy Bentham prophesied a controversy over animal rights as early as in $1789,,^{162}$ this anthropocentric point of view is the feature which distinguishes the early-modern from the present-day debates about animal experimentation. Man's dominion over the "brute creation" was still undisputed, and this applied to the issue of animal experimentation as well.

\footnotetext{
159 There is only a fairly remote reminder of this style in a rhetorical metaphor by Johnson's friend Edmund Burke, who accused his opponents of political experimentation with men, just as the "philosophers" did with "mice in an air pump, or in a recipient of mephitick gas", or as cats, "the velvet-pawed, green-eyed philosophers", with their "long-tailed" prey. Cf. A letter from . . Edmund Burke to a noble lord on the attacks made upon him and his pension, in the House of Lords, London, Owen and Rivington, 1796, pp. 62-3; see also Stevenson, op. cit., note 4 above, p. 155.

$160 \mathrm{Cf}$. Duncan, op. cit., note 3 above, pp. 182-5.

161 See French, op. cit., note 4 above, pp. 375-89.

162 See Jeremy Bentham, Collected works, ed. J. H. Burns, vol. 2.1, An introduction to the principles of morals and legislation, ed. J. H. Burns and H. L. A. Hart, London, Athlone Press, 1970, pp. 282-3; see also Maehle and Tröhler, op. cit., note 4 above, pp. 37-9.
} 